\title{
Gas Exchange, Stem Water Potential and Xylem Flux on Some Grapevine Cultivars Affected by Esca Disease
}

\author{
L. Andreini ${ }^{1 *}$, G. Caruso ${ }^{2}$, C. Bertolla ${ }^{2}$, G. Scalabrelli², R. Viti² and R. Gucci ${ }^{2}$ \\ (1) Scuola Superiore Sant'Anna di Studi Universitari e di Perfezionamento, Via S. Cecilia, 3 - 56127 Pisa \\ (2) Dipartimento di Coltivazione e Difesa delle Specie Legnose "G. Scaramuzzi”, Università di Pisa, Via del Borghetto, 80 - 56126 Pisa
}

Submitted for publication: August 2009

Accepted for publication: September 2009

Key words: Vitis vinifera L., esca disease, photosynthesis, stem water potential, conductivity

\begin{abstract}
The effect of esca disease on gas exchange, stem water potential and xylem flux of adult grapevines of Cabernet Sauvignon, Sangiovese and Trebbiano cultivars was studied over three growing seasons. Water relations were measured at véraison and cluster ripening on three types of vines: i) healthy (control); ii) symptomatic and iii) apparently healthy in the year of measurements but that had showed esca symptoms in the previous season. Xylem flux was determined on cane segments by perfusion using a tracing dye before and after the appearance of esca symptoms. Esca induced a marked reduction (about $\mathbf{7 0 \%}$ ) in carbon assimilation and stomatal conductance, especially in Cabernet Sauvignon and Sangiovese. Esca did not affect the stem water potential. Gas exchange parameters measured before the symptoms appeared in plants affected by esca were similar to those of healthy plants. Measurements made one month before the appearance of the symptoms cannot be used as screening method to determine whether the vine will show esca. No differences in dye translocation were found before the symptoms' appearance. However, a decrease in xylem flux was measured in symptomatic vines of Cabernet Sauvignon. After the appearance of esca symptoms, only the Trebbiano had a lower xylem flux than the healthy vines.
\end{abstract}

Esca is one of the most destructive diseases of the woody tissues of grapevine (Vitis vinifera L.) around the world, and it leads to significant losses in wine production. Esca is a complex disease, in which multiple fungal species, namely Phaeomoniella chlamydospora, Phaeoacremonium aleophilum (Crous et al., 1996; Mugnai et al., 1996; Larignon \& Dubos, 1997; Crous \& Grams, 2000) and Fomitiporia mediterranea (Cortesi et al., 2000; Fischer, 2002; Fischer \& Kassemeyer, 2003), are found to be associated with the development of the syndrome. Furthermore, other exogenous factors, such as climatic conditions (Dubos et al., 2002.) or training system (Geoffrion \& Renaudin, 2002), may enable symptom appearance (Graniti et al., 2000). As yet there is no effective treatment and the use of the only chemical treatment (sodium arsenite) has been forbidden. Thus, characterising the impact of esca on grapevine physiology represents a key step in pointing out a target that could enable control of this disease (Petit et al., 2006).

The esca symptoms are associated with a general decline, which includes deformed and chlorotic leaves, precocious fading, lack of vigour, plugging of the xylem vessels and trunk dieback due to the formation of cankers in the vascular tissue (Martin \& Cobos, 2007). The year-to-year unpredictable discontinuity in symptom expression is a characteristic trait of esca disease (Surico et al., 2000). Apart from the occasional delayed sprouting of escaaffected vines in the spring, external symptoms in the Northern Hemisphere develop on the crown between June and September, either through the entire vine or on single branches (Mugnai et al., 1999). Esca primarily affects mature grapevine and is caused by a sequence of several fungi in different parts of the wood, and specific symptoms and damage has recently been attributed to these fungi (Surico et al., 2000). Esca symptoms appear in severe or chronic forms (Arnaud \& Arnaud, 1931; Chiarappa, 1959; Baldacci et al., 1962; Branas, 1974; Dubos \& Larignon, 1988; Galet, 1977), although both can occur alone or together on the same plant (Larignon \& Dubos, 1997). It is important to note that another disease that presents symptoms similar to esca disease can be observed in the vineyard. In France, this disease is called black dead arm and it is characterised by two forms: severe and mild (Larignon et al., 2001).

The chronic form of esca is characterised by a deterioration in foliage. The leaves have interveinal islands of chlorotic and yellowish tissue, which later becomes necrotic. Leaf chlorosis caused by esca suggests that photosynthesis may be perturbed (Bertamini et al., 2002).

The vascular occlusion due to gels and gums secreted by the diseased xylem parenchyma cells, or even due to high-molecular weight compounds produced by the pathogen(s), determine the water stress (Mugnai et al., 1999). Since stomatal closure in response to water stress can occur even before detectable changes in leaf water potential, the stomatal conductance may be a useful indicator of grapevine water stress (Flexas et al., 2002; Cuevas et al., 2006). The purpose of this study was to analyse

*Corresponding author: e-mail: landreini@sssup.it

Acknowledgements: This research study was commissioned via ARSIA-Toscana (Regional Agency for Development and Innovation in Agriculture and Forest) by fourteen administrative regions and one autonomous province, and financed with funds provided by the 'Ministero per le Politiche Agricole e Forestali'(Ministry for Agriculture and Forestry Policy) to implement the inter-regional project "Grapevine Esca: research and experiment in the nursery and in the field for prevention and cure" (MESVIT). 
the gas exchange, stem water potential and xylem flux when the grapevines were affected by esca. Therefore, we tested whether gas exchange parameters could be used as early indicators of esca disease before the appearance of visual symptoms, and the photosynthetic damage due to esca in genotypes with different susceptibility to the disease.

\section{MATERIALS AND METHODS}

The work was carried out from 2005 to 2007 in a vineyard located at the Colignola experimental station of University of Pisa (altitude $\left.6 \mathrm{~m}, 43^{\circ} 02^{\prime} \mathrm{N}, 10^{\circ} 36^{\prime} \mathrm{E}\right)$ planted at $3 \times 1 \mathrm{~m}$ distance with Vitis vinifera L. cultivars Cabernet Sauvignon, Sangiovese and Trebbiano (grafted onto 1103P rootstock) in 1981. In the vineyard, which was trained to a high free cordon, all cultural practices (pruning, fertilisation and plant protection) were done on the same date and in the same way for all varieties. The soil was uniform across the experimental plot ( $42 \%$ sand, $37 \%$ silt and $21 \%$ clay, $\mathrm{pH} 8$ ).

In $2005 / 2006$, the study was conducted on Cabernet Sauvignon, Sangiovese and Trebbiano varieties, while in 2007 the measurements were made only on Cabernet Sauvignon, a genotype known to be very susceptible to esca disease (Christen et al., 2007; Borgo et al., 2008).

The measurements were performed on three different groups of vines: (i) symptomatic vines, which were considered diseased, considering only the green part of the leaves (ES); (ii) vines that never showed any esca symptoms; these were presumed to be healthy and considered the control (NoES); and (iii) exsymptomatic vines that had been symptomatic in previous years and that could be expected to show foliar symptoms again (ExES).

\section{Observation of esca symptomatology}

Beginning from 2005, visual observations were made periodically from June to September to determine the maximum percentage of incidence of esca disease foliar chronic symptoms [(n. of symptomatic plants/total n. of plants)*100]. At each inspection, 44, 45 and 85 plants of Cabernet Sauvignon, Trebbiano and Sangiovese respectively were examined.

\section{Gas exchange parameters}

In 2006/2007, the net $\mathrm{CO}_{2}$ assimilation rate (A), stomatal conductance $\left(\mathrm{g}_{\mathrm{s}}\right)$ and substomatal $\mathrm{CO}_{2}$ concentration $\left(\mathrm{C}_{\mathrm{i}}\right)$ of fullyexpanded leaves (from the median part of shoot) were measured at véraison and cluster ripening (corresponding to stage 81 and 85 of the $\mathrm{BBCH}$ scale respectively), between 10:30 and 12:30 (solar time) using a CIRAS 1 (PP Systems International, Hitchin Herts, UK) infrared gas analyser at photosynthetic photon flux $(\mathrm{PPF})>900 \mu \mathrm{mol} \mathrm{m} \mathrm{s}^{-2}$, leaf temperature ranging from $26.7 \pm 0.6$ to $32.6 \pm 1.2^{\circ} \mathrm{C}$, and ambient $\mathrm{CO}_{2}$ partial pressure ranging from $35.0 \pm 1.1$ to $36.0 \pm 0.2 \mathrm{mPa}$. The measurements were replicated on four different plants for each cultivars (Cabernet Sauvignon, Sangiovese, and Trebbiano) and treatment (NoEs, ES, ExES).

\section{Stem water potential}

Stem water potential $\left(\psi_{w}\right)$ was measured between 09:30 and 11:00 (solar time) after shading fully-expanded median leaves with aluminium foil for $40 \mathrm{~min}$ using a PMS 1000 pressure chamber (Plant Moisture Systems, USA). The leaf was excised and pressurised using nitrogen as a gas at a pressurisation rate of 0.0033 $\mathrm{MPa} \mathrm{s}^{-1}$ (Costagli et al., 2003).
Gas exchange and stem water potential measurements were taken on two leaves for the ES vines: a symptomatic leaf and an asymptomatic leaf collected from the apparently healthy shoot, and on one leaf for the NoES and ExEs vines. Moreover, in 2007, and only on Cabernet Sauvignon, the gas exchange and stem water potential of healthy vines (NoES) and vines that had shown esca disease for a different number of years (ExES) were compared. The latter vines were specifically those that had been symptomatic in 2006 (E06) and in 2005/2006/2007 (E05-06-07), and each group included three replication plants.

\section{Xylem flux}

The xylem flux was determined from 2005 to 2007 on shoot segments by perfusion using a dye solution of $1 \%$ azosulfamide (Bartolini \& Giorgelli, 1994). Before esca foliar symptoms appearance (May), shoots were collected from the NoES and ExES plants, while after the appearance of esca foliar symptoms (JuneJuly), the material was collected from the NoES and ES plants. In order to sample material with the same age and homogeneous characteristics, three shoots with similar length (about 100 and $130 \mathrm{~cm}$ for before and after esca appearance, respectively) were selected for each treatment. The shoots (with leaves) were vertically kept dipped in dye solution that covered about the first $15 \mathrm{~cm}$ of the shoot base for $3 \mathrm{~h}$. After immersion, the shoots were dissected every $10 \mathrm{~cm}$, beginning from the base, at the level of the nodes and internodes. The sections were observed under a stereomicroscope equipped with a digital camera and the following parameters were estimated: the percentage of coloured area in the transversal sections by the imagine analysis software (Image tool 3.00 ), and the percentage of length in the shoot reached by the dye [(length of shoot coloured/total length of shoot)*100].

\section{Statistical procedures}

A randomised block with four replications of 15 plants each was used. Data were taken over the years on three replications per type of leaf (symptomatic and asymptomatic) for each cultivar. Data were processed by analysis of variance and mean separation performed by least significant differences (LSD test, $\mathrm{P} \leq 0.05$ ).

\section{RESULTS AND DISCUSSION}

The mean of symptomatic grapevines identified in the vineyard during the three years was $30 \%$, without significant differences among the years (Table 1). The Cabernet Sauvignon showed a more stable and higher esca incidence: the percentage of symptomatic grapevines reached about $50 \%$. The percentage of symptomatic vines of Trebbiano and Sangiovese was characterised by an important annual fluctuation of symptoms from year to year, and their values for the diseased grapevines was, on average, about $50 \%$ lower in relation to the Cabernet Sauvignon (Table 1). Moreover, the values of the percentage of symptomatic vines were almost constant in Cabernet Sauvignon. These results indicate that genetic factors probably have a great influence on susceptibility to esca disease and on the appearance of symptoms (Marchi, 2001; Christen et al., 2007; Borgo et al., 2008).

\section{Gas exchange and stem water potential in the year 2006 \\ Comparison between healthy and symptomatic vines during 2005}

In 2006, the $\mathrm{CO}_{2}$ assimilation rate (A), stomatal conductance $\left(\mathrm{g}_{\mathrm{s}}\right)$ and stem water potential $\left(\psi_{\mathrm{w}}\right)$ were measured on healthy leaves belonging to healthy vines (NoES) and on asymptomatic 
leaves belonging to vines that showed esca symptoms in 2005 (ExES). The comparison of gas exchange parameters and stem water potential between treatments did not show any significant differences in both July and September (Table 2).

\section{Comparison between healthy and symptomatic leaves belonging to symptomatic vines}

The comparison between healthy and symptomatic leaves belonging to vines affected by esca disease (ES), done in July, showed that the presence of symptoms is associated with a strong reduction in $\mathrm{CO}_{2}$ assimilation rate and stomatal conductance, as well as with a significant increase in internal $\mathrm{CO}_{2}$ concentration (Table 3). The cultivars more susceptible to esca disease are Cabernet Sauvignon and Sangiovese, and their symptomatic leaves showed values for $\mathrm{A}$ and $\mathrm{g}_{\mathrm{s}}$ of about one-third of the values recorded on healthy leaves, namely of 13.2 to $14.1 \mu \mathrm{mol} \mathrm{CO}_{2} \mathrm{~m}^{-2}$ $\mathrm{s}^{-1}$ for $\mathrm{CO}_{2}$ assimilation and of 278 to $251 \mathrm{mmol} \mathrm{CO}_{2} \mathrm{~m}^{-2} \mathrm{~s}^{-1}$ for gs respectively. In these cultivars, the symptomatic leaves exhibited a little higher (about 15\%) internal $\mathrm{CO}_{2}$ concentration in relation to

\section{TABLE 1}

Percentage of symptomatic grapevines recorded each year, from 2005 up to 2007, in the Trebbiano, Sangiovese and Cabernet Sauvignon cultivars.

\begin{tabular}{lcccc}
\hline & $\mathbf{2 0 0 5}$ & $\mathbf{2 0 0 6}$ & $\mathbf{2 0 0 7}$ & $\overline{\mathbf{X}}$ \\
\hline Trebbiano & 31 & 16 & 18 & $21.7^{\mathrm{b}}\left(4,70^{*}\right)$ \\
Sangiovese & 28 & 18 & 21 & $22.3^{\mathrm{b}}(2,96)$ \\
Cabernet S. & 43 & 43 & 53 & $46.3^{\mathrm{a}}(3.33)$ \\
$\overline{\mathrm{X}}$ & $34.0\left(4.58^{*}\right)^{\mathrm{ns}}$ & $25.7(8.69)^{\mathrm{ns}}$ & $30.7(11.2)^{\mathrm{ns}}$ & $30.1(4.47)$ \\
\hline
\end{tabular}

Mean values within a column followed by different letters are significantly different ( $\mathrm{t}$ test, $\mathrm{P} \leq 0.05)$.

* Standard error

\section{TABLE 2}

Mean values of $\mathrm{CO}_{2}$ assimilation $\left(\mathrm{A}, \mu \mathrm{mol} \mathrm{CO} \mathrm{CO}^{-2}\right)$, stomatal conductance $\left(\mathrm{g}_{\mathrm{s}}, \mathrm{mmol} \mathrm{CO}_{2} \mathrm{~m}^{-2} \mathrm{~s}^{-1}\right)$, internal $\mathrm{CO}_{2}$ concentration $(\mathrm{Ci}$, $\mu \mathrm{l}$ $\left.\mathrm{L}^{-1}\right)$ and stem water potential $\left(\Psi_{\mathrm{w}},-\mathrm{MPa}\right)$ measured in 2006, on July 28 and September 20, in healthy (NoES) and ex-symptomatic vines (ExES: vines symptomatic only during the 2005 year) of Cabernet Sauvignon, Sangiovese and Trebbiano.

\begin{tabular}{|c|c|c|c|c|c|c|c|c|c|}
\hline \multicolumn{10}{|c|}{ July 28} \\
\hline & \multicolumn{3}{|c|}{ Cabernet Sauvignon } & \multicolumn{3}{|c|}{ Sangiovese } & \multicolumn{3}{|c|}{ Trebbiano } \\
\hline & NoES & ExES & $L S D$ & NoES & ExES & $L S D$ & NoES & ExES & $L S D$ \\
\hline $\mathrm{A}$ & 13.6 & 15.7 & 5.3 & 13.6 & 16.5 & 9.7 & 15.2 & 12.8 & 4.3 \\
\hline $\mathrm{g}_{\mathrm{s}}$ & 236 & 286 & 118 & 231 & 247 & 49 & 350 & 217 & 185 \\
\hline $\mathrm{C}_{\mathrm{i}}$ & 225 & 247 & 67 & 219 & 205 & 70 & 220 & 205 & 58 \\
\hline$\Psi_{w}$ & 0.98 & 0.77 & 0.34 & 0.77 & 0.82 & 0.36 & 0.84 & 0.86 & 0.12 \\
\hline \multicolumn{10}{|c|}{ September 20} \\
\hline A & 13.0 & 12.4 & 7.1 & 14.0 & 12.7 & 5.4 & 11.6 & 12.6 & 6.1 \\
\hline $\mathrm{g}_{\mathrm{s}}$ & 205 & 225 & 115 & 221 & 201 & 73 & 185 & 204 & 75 \\
\hline $\mathrm{C}_{\mathrm{i}}$ & 219 & 235 & 31 & 219 & 220 & 29 & 225 & 224 & 26 \\
\hline$\Psi_{\mathrm{w}}$ & 0.98 & 0.88 & 0.35 & 0.74 & 0.96 & 0.46 & 0.73 & 0.85 & 0.37 \\
\hline
\end{tabular}

Mean were separated by LSD test $(\mathrm{P} \leq 0.05)$ after analysing of variance within each cultivar and sampling date. the healthy leaves. In Trebbiano, the symptomatic leaves showed an assimilation rate level corresponding to half that of the healthy leaves $\left(14.2 \mu \mathrm{mol} \mathrm{CO} \mathrm{m}^{-2} \mathrm{~s}^{-1}\right)$. Although the symptomatic leaves showed a reduction in stomatal functioning (about 36\%) and an increase (about 20\%) in internal $\mathrm{CO}_{2}$ concentration (Table 3), these differences were not significant. The higher values of $\mathrm{Ci}$ in the asymptomatic leaves collected on the ES vines in September could be explained by their much higher stomatal conductance than of the of symptomatic leaves.

In diseased plants of all cultivars the gas exchange values $\left(\mathrm{A}, \mathrm{g}_{\mathrm{s}}\right)$ recorded in the asymptomatic leaves were high and similar to those of the control (Tables 2 and 3), as observed by Mattii and Gorini (2009). In addition, the authors showed a significant reduction in net photosynthesis about 10 days before the symptoms appearance. This means that measurements made one month before symptoms appearance cannot be used as a screening method to determine whether the vine will show esca disease symptoms.

The stem water potential of the symptomatic leaves ranged between -0.81 to $-0.98 \mathrm{MPa}$ in all cultivars. Similar values were recorded in the healthy leaves (Table 3).

In September, the effect of esca disease on gas exchange parameters was the same as in July, except for $\mathrm{C}_{\mathrm{i}}$, which was not affected by esca (Table 3). In Cabernet Sauvignon and Trebbiano, the $\mathrm{CO}_{2}$ assimilation rate of the symptomatic leaves (3.6-3.3 $\mu \mathrm{mol} \mathrm{CO} \mathrm{m}^{-2} \mathrm{~s}^{-1}$ respectively) was about $25 \%$ of that of the healthy leaves (12.5-13.5 $\mu \mathrm{mol} \mathrm{CO} \mathrm{CO}_{2}^{-2} \mathrm{~s}^{-1}$ for the two cultivars respectively). In Sangiovese the reduction was less (about 50\% in respect to that of the healthy leaves). Also, $g_{s}$ was reduced in the diseased leaves, especially in Cabernet Sauvignon, where the decrease in $g_{s}$ amounted to $60 \%$. In the other two cultivars, the reduction in stomatal functioning resulted in a decrease of about $45 \%$. In diseased plants, as observed in July, the $\psi_{w}$ of the symptomatic leaves did not show significant differences relative to the healthy leaves. 


\section{TABLE 3}

Mean values of $\mathrm{CO}_{2}$ assimilation $\left(\mathrm{A}, \mu \mathrm{mol} \mathrm{CO} \mathrm{m}^{-2}\right)$, stomatal conductance $\left(\mathrm{g}_{\mathrm{s}}\right.$, mmol CO $\left.\mathrm{m}^{-2} \mathrm{~s}^{-1}\right)$, internal $\mathrm{CO}_{2}$ concentration $\left(\mathrm{Ci}\right.$, $\left.\mu 1 \mathrm{~L}^{-1}\right)$ and stem water potential $\left(\Psi_{\mathrm{w}},-\mathrm{MPa}\right)$, measured in symptomatic vines (ES) in 2006, on July 28 and September 20, comparing symptomatic (Sym) and asymptomatic (Asym) leaves of Cabernet Sauvignon, Sangiovese and Trebbiano vines.

\begin{tabular}{|c|c|c|c|c|c|c|c|c|c|}
\hline \multicolumn{10}{|c|}{ July 28} \\
\hline & \multicolumn{3}{|c|}{ Cabernet Sauvignon } & \multicolumn{3}{|c|}{ Sangiovese } & \multicolumn{3}{|c|}{ Trebbiano } \\
\hline & Asym & Sym & $L S D$ & Asym & Sym & $L S D$ & Asym & Sym & $L S D$ \\
\hline $\mathrm{A}$ & 13.2 & 3.7 & 3.1 & 14.1 & 4.7 & 3.8 & 14.2 & 6.0 & 6.0 \\
\hline$g_{s}$ & 278 & 99 & 60 & 251 & 105 & 81 & 272 & 175 & 142 \\
\hline $\mathrm{C}_{\mathrm{i}}$ & 223 & 254 & 29 & 215 & 249 & 13 & 215 & 257 & 50 \\
\hline$\Psi_{\mathrm{w}}$ & 0.82 & 0.98 & 0.19 & 0.86 & 0.87 & 0.08 & 0.81 & 0.86 & 0.19 \\
\hline \multicolumn{10}{|c|}{ September 20} \\
\hline A & 12.5 & 3.6 & 5.8 & 12.3 & 6.5 & 6.6 & 13.5 & 3.3 & 11.6 \\
\hline$g_{s}$ & 249 & 102 & 87 & 226 & 132 & 43 & 224 & 124 & 125 \\
\hline $\mathrm{C}_{\mathrm{i}}$ & 285 & 241 & 114 & 234 & 254 & 60 & 235 & 301 & 112 \\
\hline$\Psi_{\mathrm{w}}$ & 0.94 & 0.84 & 0.43 & 0.70 & 0.73 & 0.19 & 0.82 & 0.75 & 0.41 \\
\hline
\end{tabular}

Means were separated by the LSD test $(\mathrm{P} \leq 0.05)$ after analysis of variance for each cultivar and sampling date.

\section{TABLE 4}

Mean values of $\mathrm{CO}_{2}$ assimilation $\left(\mathrm{A}, \mu \mathrm{mol} \mathrm{CO} \mathrm{m}^{-2}\right)$, stomatal conductance $\left(\mathrm{g}_{\mathrm{s}}, \mathrm{mmol} \mathrm{CO}_{2} \mathrm{~m}^{-2} \mathrm{~s}^{-1}\right)$ and internal $\mathrm{CO}_{2}$ concentration $(\mathrm{Ci}$, $\left.\mu \mathrm{L}^{-1}\right)$, measured before esca appearance $(19 / 06 / 07)$, and stem water potential $\left(\Psi_{\mathrm{w}},-\mathrm{MPa}\right)$ measured before and after $(18 / 07 / 07)$ esca appearance in Cabernet Sauvignon. The following treatments (replication of three vines) were compared: healthy vines (NoES) and ExES vines symptomatic in 2006 (E06) and in 2005-2006-2007 (E05-06-07).

\begin{tabular}{|c|c|c|c|c|c|c|}
\hline & \multicolumn{3}{|c|}{ Gas exchange parameters } & \multicolumn{3}{|c|}{ Stem water potential } \\
\hline & \multicolumn{3}{|c|}{$19 / 06 / 07$} & \multirow{2}{*}{$\frac{19 / 06 / 07}{\text { Healthy }}$} & \multicolumn{2}{|c|}{ 18/07/07 } \\
\hline & $\mathrm{A}$ & $\mathrm{g}_{\mathrm{s}}$ & $\mathrm{C}_{\mathrm{i}}$ & & Healthy & With symptom \\
\hline NoES & 16.6 & 295 & 199 & 0.58 & 0.63 & $*$ \\
\hline E 06 & 15.9 & 302 & 217 & 0.50 & 0.58 & $*$ \\
\hline E $05-06-07$ & 16.6 & 294 & 216 & 0.57 & 0.50 & 0.68 \\
\hline LSD & 3.4 & 89 & 18 & 0.14 & 0.23 & n.d. \\
\hline
\end{tabular}

*Vines without symptomatic leaves

Means were separated by the LSD test $(\mathrm{P} \leq 0.05)$ after analysis of variance for each cultivar and sampling date.

In all the cultivars, esca symptoms provoked a drastic reduction in the $\mathrm{CO}_{2}$ assimilation rate and in stomatal conductance, and an increase in intercellular $\mathrm{CO}_{2}$ concentration. Similar effects were reported by Petit et al. (2006). These results suggest that esca foliar symptoms do not seem to be due to water stress. Other factors, such as the presence and translocation of phytotoxins produced by fungi, are more likely to be responsible for leaf chlorosis (Sparapano et al., 2000; 2001). On the contrary, in both the symptomatic and healthy leaves the stem water potential was not affected by esca disease because the values have been preserved at the same levels of the no-stressed vines.

Gas exchange and stem water potential in the year 2007

Comparison between Cabernet Sauvignon vines characterised by different numbers of symptomatic years

Before (June) and after (July) the appearance of esca symptoms, the gas exchange parameters and stem water potential of the ExES vines did not show significant differences relative to the control leaves (Table 4).

The vines E 05-06-07 that did not show esca symptoms in June showed foliar symptoms of the disease later in the season. This occurrence is not an obvious consequence, because esca disease is characterised by annual fluctuation in the appearance of symptoms. The presence and manifestation of esca disease for repeated years (E 05-06-07) did not induce significant differences in stem water potential in relation to the control vines and vines symptomatic for only one year (E 06). Moreover, the mean values of $\psi_{\mathrm{w}}$ for the asymptomatic and symptomatic leaves $(-0.5$ and $-0.68 \mathrm{MPa}$ respectively) of the $\mathrm{E}$ 05-06-07 vines were significantly different $(\mathrm{LSD}=0.146)$ in 2007 , which had not been the case in previous years. 


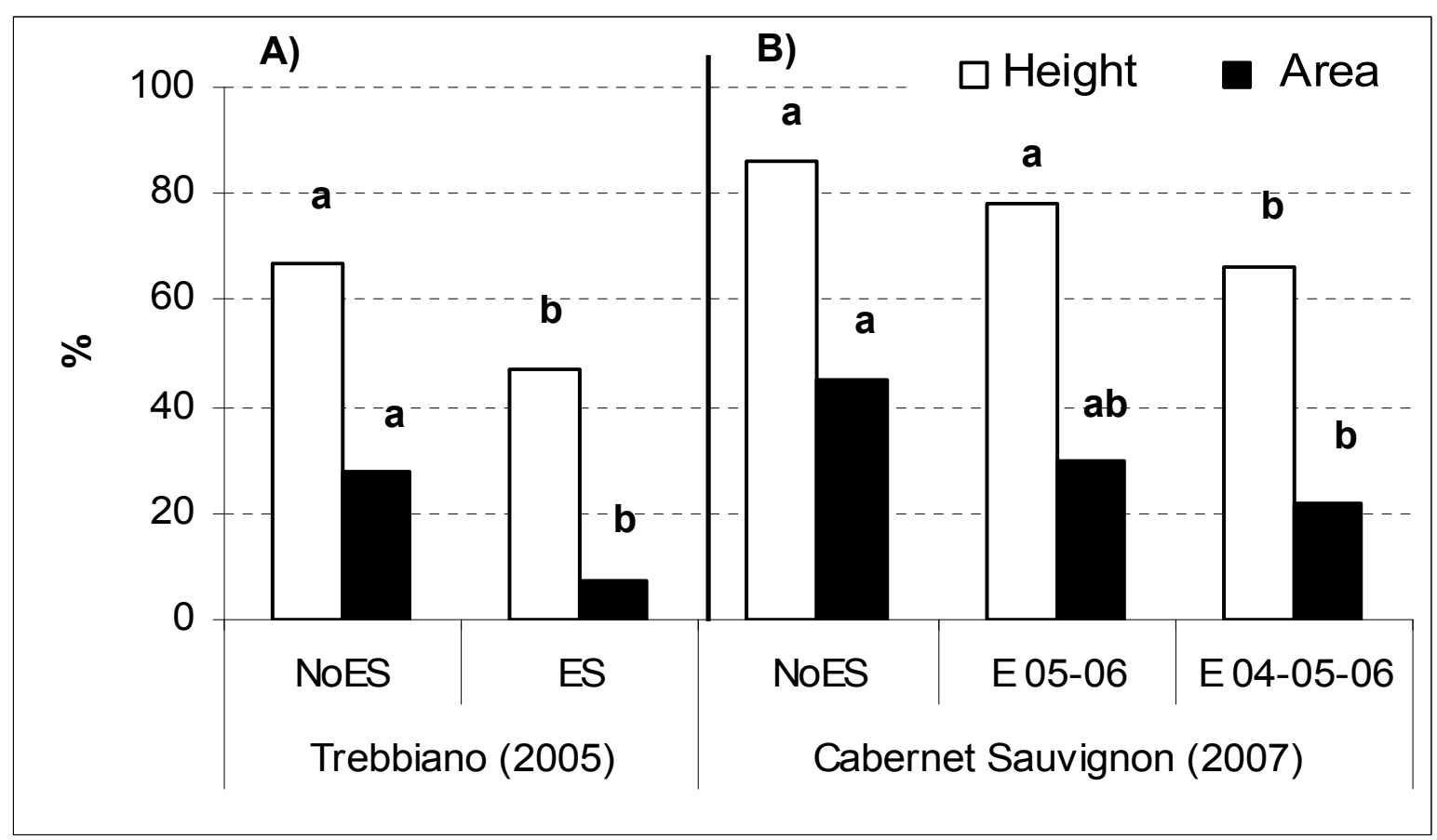

FIGURE 1

Mean percentage of height reached by tracing dye ( $\square$ ) and xylematic area coloured ( $\mathbf{a})$ in shoots collected: A) after symptom appearance in Trebbiano control vines (NoES) and symptomatic vines (ES) in 2005; B) before symptom appearance in Cabernet Sauvignon control vines (NoES) and ex-symptomatic vines for two (E 05-06) and three (E 04-05-06) consecutive years in 2007. Different letters correspond to significant differences for the LSD test, P $\leq 0.05$.

\section{Xylem flux}

The xylematic flux analysis of shoots made in the three-year period (2005-2007) in all the cultivars showed variable results. Before the appearance of esca symptoms, a regular translocation of tracing dye was observed in the NoES vines of all cultivars because the xylem vessels were not obstructed. Over two consecutive years (2005/2006), the symptomatic shoots of Trebbiano showed a reduced level of translocation. In 2005 in particular, the tracing dye reached $47 \%$ of the diseased shoot length, while it reached about $70 \%$ in the control shoot (Fig. 1). In 2006, the results were not significant due to the high variability of data, but they showed a similar trend to that observed in 2005 (data not shown). Similarly, in the sections made at $30 \mathrm{~cm}$ shoot length from the base, the xylematic area percentage that was perfused by dye represented $7 \%$ and 30\% in the diseased and control shoots respectively (Fig. 1).

In 2007, before the appearance of esca symptoms, the Cabernet Sauvignon vines that had been symptomatic in all previous years (E 04-05-06) showed a low xylematic flux with respect to the control vines (Fig. 1). This reduction in xylematic flux suggests that the recurrence of esca disease for several years weakens the physiological status of the plant. This lower xylem sap translocation could be related to important vascular damage at the level of the woody trunk: anatomical observations showed an significant deterioration in the wood, with deep brown or black streaks and necrotic areas (Mugnai et al., 1999). However, after the appearance of esca symptoms, no significant differences were noted (data not shown). Further investigations are necessary to clarify the situation, because a low xylematic flux was observed in Cabernet Sauvignon before the appearance of esca symptoms, while a normal flux was detected after the appearance of esca symptoms.

\section{CONCLUSION}

The results confirm that vulnerability to esca disease is influenced strongly by genotype. Cabernet Sauvignon in particular appears highly susceptible to esca disease, as is evident from the high percentage of symptomatic vines. In relation to Sangiovese and Trebbiano we observed that the number of symptomatic and asymptomatic vines was less than in Cabernet Sauvignon, and that the appearance of symptoms was more variable. It is likely that the evidence of symptoms is enhanced by conditions of humidity and that differences in precipitation and distribution between the years of study may explain the variability in the appearance of symptoms appearance. However, the number of sick vines in the case of Cabernet Sauvignon probably remained high despite the changing in climate conditions because of the high susceptibility of this cultivar to esca.

Although our results are preliminary, it appears that gas exchange and water relation parameters are not particularly useful to detect differences in response and susceptibility between cultivars. In fact, although symptomatic leaves showed a dramatic decrease in A and gs values, it appeared similar when healthy vines of three cultivars were compared. However, the experimentation with xylem conductivity and water relations in grapevines affected by esca may be useful for a better understanding of the progressive loss in functionality caused by this subtle disease.

In all the cultivars, the gas exchange values of the asymptomatic leaves belonging to sick plant were high and typical of healthy leaves, as they were characterised by a good stomatal functioning. This observation suggests that, when the illness does not appear, the leaf response of the infected grapevines can be similar to that of healthy vines and that the measurements taken one month 
before the appearance of symptoms cannot be used as a screening method to detect early symptoms of esca.

In conclusion, since the mechanisms of esca development still have to be clarified, an approach combining the physiological and pathological aspects appears promising to understand how esca disease affects the survival and functioning of grapevines.

\section{LITERATURE CITED}

Arnaud, G. \& Arnaud, M., 1931. Esca. In: Traité de pathologie végétale (Le Chevalier ed.) Paris, Volume 1. 428-444.

Baldacci, E., Belli, G. \& Fogliani, G., 1962. Osservazioni sulla sintomatologia e sull'epidemiologia della carie del legno di vite (Mal dell'esca) de Phellinus (Fomes) igniarius (L. ex Fr.) Patouillard. Rivista di Patologia Vegetale 2, 165-184.

Bartolini, S. \& Giorgelli, F., 1994. Observations on development of vascular connections in two apricot cultivars. Adv. Horticult. Sci. 8, 97-100.

Bertamini, M., Nedunchezhian, N., Tomasi, F. \& Grando, M.S., 2002. Phytoplasma [Stolbur-subgroup (Bois Noir-BN)] infection inhibits photosynthetic pigments, ribulose-1,5-bisphosphate carboxylase and photosynthetic activities in field grown grapevine (Vitis vinifera L. cv. Chardonnay) leaves. Physiol. Mol. Plant Pathol. 61,357-366.

Borgo, M., Bellotto, D., Dal Cortivo, G.L., Zanzotto, A., Tosi E. \& Marchesini E., 2008. Sensibilità varietale al mal dell'esca della vite nel veneto. Atti Giornate Fitopatologiche 2, 223-230.

Branas, J., 1974. Viticulture (Dehan Ed.). Montpellier, France. Ecole Nationale Supérieure Agronomique.

Chiarappa, L., 1959. Wood decay of the grapevine and its relationships with black measles disease. Phytopathol. 49, 510-519.

Christen, D., Schonmann, S., Jermini, M., Strasser, R.J. \& Defago, G., 2007. Characterization and early detection of grapevine (Vitis vinifera) stress responses to esca disease by in situ chlorophyll fluorescence and comparison with drought stress. Environ. Exp. Botany 60, 504-514.

Cortesi, P., Fischer, M. \& Milgroom, M.G., 2000. Identification and spread of Fomitiporia punctata associated with wood decay of grapevine showing symptoms of esca. Phytopathol. 90, 967-972.

Costagli, G., Gucci, R. \& Rapoport, H.F., 2003. Growth and development of fruits of olive 'Frantoio' under irrigated and rainfed conditions. J. Horticult. Sci. Biotechnol. 78, 119-124.

Crous, P.W. \& Grams, W., 2000. Phaoemoniella chlamydospora gen. Et comb. Nov., a causal organism of Petri grapevine decline and esca. Phytopathologia Mediterranea 39, 112-118.

Crous, P.W., Grams, W., Wingfield, M.J. \& Van Wyk, P.S., 1996. Phaeoacremonium gen. nov. associated with wilt and decline disease of woody hosts and human infections. Mycologia 88, 786-796.

Cuevas, E., Baeza, P. \& Lissarrague, J.R., 2006. Variation in stomatal behaviour and gas exchange between mid-morning and mid-afternoon of north-south oriented grapevines (Vitis vinifera L. cv. Tempranillo) at different levels of soil water availability. Scientia Horticulturae 108, 173-180.
Dubos, B. \& Larignon, P., 1988. Esca and black measles. In: Pearson, R.C. \& Goheen, A.C. (eds). Compendum of grape diseases, APS, St. Paul, Minnesota. pp. 34-35.

Dubos, B., Larignon, P., Lecomte, P., Magnien, C., Panon, M.-L., Grand, O., Laveau, E. \& Leguay, M., 2002. Les maladies du bois en viticulture. ITV France $113,32-35$.

Fischer, M., 2002. A new wood-decaying basidiomycete species associated with esca of grapevine: Fomitiporia mediterranea (Hymenochaetales). Mycological Progress 1, 315-324.

Fischer, M. \& Kassemeyer, H.H., 2003. Fungi associated with esca disease of grapevine in Germany. Vitis 42, 109-116.

Flexas, J., Bota, J., Escalona, J.M., Sampol, B. \& Medrano, H., 2002. Effects of drought on photosynthesis in grapevines under field conditions: an evaluation of stomatal and mesophyll limitations. Functional Plant Biol. 29, 461-471.

Galet, P., 1977. Apoplexie In: Les maladies et les parasites de la vigne, Vol. I. Imp. Paysan du Midi, Montpellier. pp. 409 - 430.

Geoffrion, R. \& Renaudin, I., 2002. Tailler contre l'esca de la vigne. Phytoma 554, 23-27.

Graniti, A., Surico, G. \& Mugnai, L., 2000. Esca of grapevine: a disease complex or a complex of diseases? Phytopathologia Mediterranea 39, 16-20.

Larignon, P. \& Dubos, B., 1997. Fungi associated with esca disease in grapevine. Eur. J. Plant Pathol. 103, 147-157.

Larignon, P., Fulchic, R., Cere, L. \& Dubos, B., 2001. Observation on black dead arm in French vineyards. Phytopathologia Mediterranea 40, 336-342.

Marchi, G., 2001. Susceptibility to esca of various grapevine (Vitis vinifera) cultivars grafted on different rootstocks in a vineyard in the province of Siena (Italy). Phytopathologia Mediterranea 40, 27-36.

Martin, M.T. \& Cobos, R., 2007. Identification of fungi associated with grapevine decline in Castilla y Leon (Spain). Phytopatologia Mediterranea 46, 18-25.

Mattii, G.B. \& Gorini, A., 2009. Physiological alterations in esca diseased vines. In: Proc. 16th International Symposium GiESCO, July 2009, Davis, California, USA. pp. $139-143$.

Mugnai, L., Graniti, A. \& Surico, G., 1999. Esca (black measles) and brown woodstreaking: two old and elusive diseases of grapevines. Plant Dis. 83, 404-418.

Mugnai, L., Surico, G. \& Esposito, A., 1996. Microflora associata al mal dell'esca della vite in Toscana. Informatore Fitopatologico 46, 49-55.

Petit, A.N., Vaillant, N., Boulay, M., Clément, C. \& Fontaine, F., 2006 Alteration of photosynthesis in grapevines affected by esca. Phytopathol. 96, 1060-1066.

Sparapano, L., Bruno, G. \& Graniti, A., 2000. Effects on plants of metabolite produced in culture by Phaeoacremonium chlamydosporum, P. aleophilum and Fomitiporia punctata. Phytopathologia Mediterranea 39, 169-177.

Sparapano, L., Bruno, G. \& Graniti, A., 2001. Three-year observation of grapevines cross-inoculated with esca-associated fungi. Phytopathologia Mediterranea 40, 376-386.

Surico, G., Marchi, G., Ferrandino, F.J., Braccini, P. \& Mugnai, L., 2000. Analysis of the spatial spread of esca in some Tuscan vineyards (Italy). Phytopathologia Mediterranea 39, 211-224. 